DOI: 10.4274/tod.galenos.2019.97759

Turk J Osteoporos 2020;26:75-80

\title{
Does Bone Mineral Density Have an Affect on the Visual Analogue Scale Pain Score?
}

\author{
Kemik Mineral Dansitesinin Vizüel Analog Skala Ağrı Skoruna Etkisi Var mıdır?
}

(D) Kenan Özler

Konya Beyşehir State Hospital, Clinic of Orthopedics, Konya, Turkey

\section{Abstract}

Objective: The objective of this study is to evaluate the Visual Analogue scale (VAS) pain scale in elderly patients with obesity and without obesity, and determine whether the VAS pain score is associated with obesity in patients with osteoporosis.

Materials and Methods: We included 192 patients in this study (69 patients with body mass index (BMI) <30 and 99 patients with BMI 230). We determined the values of bone mineral density (BMD) by the dual-energy X-ray absorptiometry method. Importantly, we evaluated the VAS pain scores in the range of "without pain" (score=0) and "the worst pain" (score=10), and divided them into three groups according to the World Health Organization's pain severity scale: mild pain (score: <3), mild-moderate pain (score: 3-6), and moderate-severe pain (score: >6). Additionally, we used a multivariate logistic regression model to identify the independent risk factors of VAS pain score in patients with osteoporosis.

Results: The VAS pain score was higher in patients with obesity than the patients without obesity $(4.49 \pm 2.76$ and $3.49 \pm .42$, respectively. $\mathrm{P}=0.014)$. Advanced age [Odds ratio $(\mathrm{OR})=1.094,95 \%$ confidence interval $(\mathrm{Cl})=1.018-1.175, \mathrm{p}=0.014$ ] and obesity $(\mathrm{OR}=0.225,95 \% \mathrm{Cl}=0.055-$ $0.928, p=0.039)$ were associated with higher VAS pain score in patients with osteoporosis. Otherwise, only advanced age $(O R=1.157,95 \%$ $\mathrm{Cl}=1.045-1.280, \mathrm{p}=0.005)$ was associated with higher VAS pain score in patients with normal BMD. Advanced age $(\mathrm{OR}=1.141,95 \% \mathrm{Cl}=1.093-$ 1.192, $\mathrm{p}=<0.001)$ and osteoporosis ( $\mathrm{OR}=0.001,95 \% \mathrm{Cl}=0.00-0.014, \mathrm{p}=<0.001)$ were associated with higher VAS pain score in all patients. Conclusion: We believe that reducing obesity, which is a variable risk factor, will benefit in pain reduction and sedentary lifestyle, and improve BMD in patients with osteoporosis.

Keywords: Osteoporosis, VAS pain score, obesity

\section{Öz}

Amaç: Bu çalışmada, obez ve obez olmayan yaşlı hastalarda Vizüel Analog skala (VAS) ağı skalasını değerlendirmeyi ve ayrıca VAS ağrı skorunun osteoporozlu hastalarda obezite ile ilişkili olup olmadığını belirlemeyi amaçladık.

Gereç ve Yöntem: Çalışmaya toplam yüz doksan iki hasta dahil edildi [vücut kitle indeksi (VKi) <30 olan 69 hasta ve VKi $\geq 30$ olan 99 hasta]. kemik mineral yoğunluğu (KMY) değerleri, dual-enerjili X-ş̧ını absorpsiyometrisi yöntemi ile belirlenmiştir. VAS ağrı skoru "ağrısız" (skor=0) ve "en kötü ağı" (skor=10) olarak değerlendirildi ve Dünya Sağlık Örgütü'nün ağrı şiddeti ölçeğine göre 3 gruba ayrıldı: skor <3 hafif ağrı, 3-6 hafif-orta derecede ağrı ve $>6$ orta-şiddetli ağrı. Osteoporoz hastalarında VAS ağrı skorunun bağımsız risk faktörlerini belirlemek için çok değişkenli bir lojistik regresyon modeli kullanıldı.

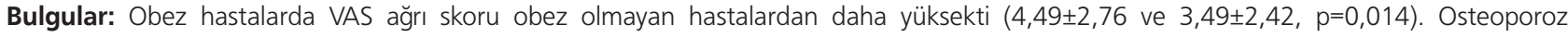
hastalarında ileri yaş [Olasılık oranı $(O R)=1,094, \% 95$ güven aralığı $(G A)=1,018-1,175, p=0,014$ ] ve obezite $(O R=0,225, \% 95$ GA=0,055-0,928, $p=0,039)$, VAS ağrı skoru ile ilişkili idi. Normal KMY olan hastalarda sadece ileri yaş VAS ağrı skoru ile ilişkili idi $(O R=1,157, \% 95 \mathrm{GA}=1,045-$ 1,280, $p=0,005)$. Tüm hastalarda ileri yaş $(\mathrm{OR}=1,141, \% 95 \mathrm{GA}=1,093-1,192, \mathrm{p}=<0,001)$ ve osteoporoz $(\mathrm{OR}=0,001, \% 95 \mathrm{GA}=0,00-0,014$, $p=<0,001)$ VAS ağrı skoru ile ilişkiliydi.

Sonuç: Değişken bir risk faktörü olan obezitenin azaltılmasının, ağıı ve sedanter yaşam tarzını azaltacağını ve osteoporozu olan hastalarda KMY'yi iyileştireceğini düşünüyoruz.

Anahtar kelimeler: Osteoporoz, VAS ağrı skoru, obezite 


\section{Introduction}

Osteoporosis is a serious health problem in the elderly population (1). Worldwide, osteoporosis was 27.5 million in 2010, and it is estimated to be 33.9 million in 2025 and increase by $23 \%$ (2). Risk factors of osteoporosis are advanced age, female gender, genetic, calcium-poor, vitamin D deficiency, protein-rich nutrition, smoking, alcohol and coffee consumption, immobilization, sedentary life and steroid-like drug use affecting bone resorption (3). Nowadays, sedentary life, which has increased as a result of the change in eating habits and technological developments, has caused obesity to become a significant health problem like osteoporosis (4). Hu et al. (5) reported that osteoporosis and obesity have some common pleiotropic genes. Neglia et al. (6) said that increased body mass index (BMI) was associated with the raised rate of osteoporosis. Also, when bone mineral density (BMD) was evaluated with dual-energy X-ray absorptiometry (DXA) and high-resolution peripheral quantitative computed tomography was not shown the difference between obese and non-obese elderly (7).

Pain is an important complaint in osteoporotic elderly population, especially in postmenopausal women (8). The findings of Ohtori et al. (9) support that increased back pain as a result of bone resorption occurs in patients with osteoporosis. Also, studies have shown that obesity is also associated with pain (10). Mohd Sallehuddin et al. (11) reported that the Visual Analogue scale (VAS) pain score was increased in obese older and younger women, and the VAS pain score was higher in obese older women than younger obese women.

Osteoporosis and increased age are manifested as the increase of pain, withdrawal from daily life, and transition to a sedentary life. In light of current findings, obesity may affect the severity of pain in the elderly population with osteoporosis. In our study, we aimed to evaluate the VAS pain scale in obese and non-obese elderly patients, and additionally determine whether the VAS pain score is associated with obesity in patients with osteoporosis.

\section{Materials and Methods}

A total of one hundred and ninety-two patients were included in the study. These patients were admitted to the outpatient clinic of Beyşehir State Hospital and whose BMD and T-scores were determined in the last year. Because, BMD scanning time varies according to the age of osteoporosis-related fracture risk factors such as pre-fragility fracture, steroid use, family history of hip fracture, age, low body weight, smoking and decreased vision. Eventually, the time of re-BMD changes according to the threshold value of BMD to evaluate the effectiveness of the treatment in osteoporosis (12). Also, DXA analysis showed no significant difference in $\mathrm{BMD}$ in the elderly without any risk factors within 24 months (13). In our study, when we look at the following exclusion criteria; patients without additional risk factors, without any medication, causing any change in bone density, and no indication for re-measurement of BMD. BMD values were determined by the DXA method (DXA, Stratos dR 2D Fan Beam Dexa, DMS GROUP). BMI was calculated by the formula of kilogram/height square meters. BMI $\geq 30$ was accepted as obese and $\mathrm{BMI}<30$ as non-obese according to the World Health Organization (WHO) classification. BMD was measured from the lumbar spine level (L1-L4), and the hips (femoral neck, trochanter, and intertrochanteric) and the unit was $\mathrm{g} / \mathrm{cm}^{2}$. Osteoporosis and osteopenia were determined according to the T-scores of the above specific localizations regions according to the $\mathrm{WHO}, \mathrm{T}$-score $\leq-2.5$ was accepted as osteoporosis and T-score between -2.5 and -1 were accepted as osteopenia.

Patients were excluded if any of the following disorders were present: spontaneous and/or post-traumatic fractures, ankylosing spondylitis, myasthenia graves, received chemotherapy and radiotherapy due to a history of bone tumor and/or systemic tumor, received medication such as biphosphonate, calcium, which could cause a change in BMD for at least one year or longer. All participants provided a written informed consent and the study protocol was approved by the Necmettin Erbakan University Meram Faculty of Medicine Local Ethics Committee (approval date: 05.04.2019, decision no: 1794).

All patients who participated in the study were evaluated at admission. Clinical histories were evaluated, and anthropometry measurements, clinical examinations were performed. VAS pain score was evaluated in the patients. Especially walking, standing, climbing stairs, squatting, pain status with sitting and/or staying were evaluated in pain assessment of VAS pain scores. The VAS pain score was assessed as "without pain" (score =0) and "the worst pain" (score =10) (14). VAS pain scale was divided into three groups according to the WHO's pain severity scale as follows: score $<3$ mild pain, 3-6 mild-moderate pain, and $>6$ moderate-severe pain (15). BMD measurements of patients who were admitted to our hospital within the last year were recorded. The study protocol was performed according to the principles of the Declaration of Helsinki and approved by the local Ethical Committee.

Routine laboratory automated techniques were used to determine serum biochemical markers of serum C-reactive protein (CRP), calcium, phosphorus, sodium, potassium and vitamin B12 [CRP (0-6 mg/L), calcium (8.2-10.2 mg/ $\mathrm{dL}$ ), phosphorus (2.5-5 mg/dL), sodium (135-145 mmol/L), potassium (3.5-5.1 mmol/L), vitamin B12 (210-915 pg/mL) and vitamin D (9.5-39.6 ng/mL). Complete blood count (CBC) parameters were measured by automated blood counter CellDyn 3700 automated hemocytometer (Abbott, IL, USA).

\section{Statistical Analysis}

The sample size required for the study was performed with the G-Power program (16). A minimum sample size of one hundred and twenty-six was needed to detect anticipated effect size of 0.3 for the regression equation, at a power level of $0.95(\beta=0.95)$ and a probability level of $0.05(\alpha=0.05)$. 
BM SPSS Statistics for Windows, version 22.0 (IBM Corp. Armonk, NY, USA) was used for statistical analysis. Variables were tested for normality by the Kolmogorov-Smirnov test Normally distributed data are presented as mean \pm standard deviations. Categorical comparisons were performed using the $\chi^{2}$-test. We used the independent samples t-test for parametric variables between $\mathrm{BMI}<30$ and $\mathrm{BMI} \geq 30$ groups. Univariate and multivariate logistic regression analysis was used to determine if a relationship between severe VAS pain score and obesity, serum biochemical and/or CBC parameters were present in patients with osteoporosis and normal BMD patients. A $p$ value $<0.05$ was considered as significant.

\section{Results}

A total of 168 participants ( $69 \mathrm{BMI}<30$ and $99 \mathrm{BMI} \geq 30$ patients) were enrolled in the study. The anthropometric and biochemical characteristics, CBC parameters, VAS pain score, and BMD measurements are given in Table 1. There were no statistically significant differences among age, CRP, calcium, phosphorus, sodium, potassium and vitamin B12, white blood cell counts, mean corpuscular volume, neutrophil lymphocyte ratio, platelet lymphocyte ratio values between groups. Osteoporosis and osteopenia distribution rates were not statistically significant between groups (Table 1). Serum vitamin D level was $10.49 \pm 3.12$ $\mathrm{ng} / \mathrm{mL}$ in the obese group, $9.09 \pm 3.06 \mathrm{ng} / \mathrm{mL}$ in the non-obese group, and was statistically significantly higher in the obese group ( $p=0.009$ ). The median VAS pain score was $4.49 \pm 2.76$ and $3.49 \pm 2.42$ in $\mathrm{BMI} \geq 30$ and $\mathrm{BMl}<30$ groups. VAS pain scores were higher in obese patients than non-obese patients $(p=0.014)$ (Table 1).

Univariate and multivariate logistic regression analysis was then used to determine a relationship between VAS pain score and biochemical, CBC parameters, and BMI in osteoporosis and normal BMD patients. Advanced age [odds ratio $(O R)=1.094$, 95\% confidence interval $(\mathrm{Cl})=1.018-1.175, \mathrm{p}=0.014]$ and $\mathrm{BMI} \geq 30$ (OR $=0.225,95 \% \mathrm{Cl}=0.055-0.928, \mathrm{p}=0.039$ ) were associated with VAS pain score in osteoporosis patients (Table 2). Otherwise, only advanced age $(\mathrm{OR}=1.157,95 \% \mathrm{Cl}=1.045$ $1.280, p=0.005$ ) was associated with VAS pain score in normal BMD patients (Table 2).

Univariate and multivariate logistic regression analysis was then used to determine a relationship between VAS pain score and other variables in all patients. Advanced age $(O R=1.141,95 \%$ $\mathrm{Cl}=1.093-1.192, \mathrm{p}=<0.001)$ and osteoporosis (OR $=0.001$, $95 \% \mathrm{Cl}=0.00-0.014, \mathrm{p}=<0.001$ ) were associated with VAS pain score in all patients (Table 3). BMI and other variables were not significantly associated with VAS pain score in all patients (Table 3).

Table 1. Anthropometric and biochemical characteristics, laboratory parameters, and BMD measurements of BMI < 30 and $\mathrm{BMI} \geq 30$ groups

\begin{tabular}{|c|c|c|c|c|}
\hline & & $\begin{array}{l}\text { BMI <30 } \\
n=69\end{array}$ & $\begin{array}{l}\text { BMI } \geq 30 \\
n=99\end{array}$ & $p^{*}$ \\
\hline \multicolumn{2}{|c|}{ Age (year) } & $57.38 \pm 9.36$ & $55.49 \pm 9.09$ & 0.194 \\
\hline \multicolumn{2}{|c|}{ VAS pain score } & $3.49 \pm 2.42$ & $4.49 \pm 2.76$ & 0.014 \\
\hline \multicolumn{2}{|c|}{ CRP (mg/L) } & $3.81 \pm 4.95$ & $4.05 \pm 5.54$ & 0.770 \\
\hline \multicolumn{2}{|c|}{ Sedimentation $(\mathrm{mm} / \mathrm{hr})$} & $15.01 \pm 1.78$ & $15.22 \pm 3.94$ & 0.958 \\
\hline \multicolumn{2}{|c|}{ Calcium (mg/dL) } & $8.79 \pm 0.63$ & $8.81 \pm 0.59$ & 0.858 \\
\hline \multicolumn{2}{|c|}{ Phosphorus (mg/dL) } & $3.53 \pm 1.43$ & $3.27 \pm 0.59$ & 0.120 \\
\hline \multicolumn{2}{|c|}{ Sodium (mmol/L) } & $139.70 \pm 2.56$ & $136.54 \pm 20.06$ & 0.195 \\
\hline \multicolumn{2}{|c|}{ Potassium (mmol/L) } & $4.17 \pm 0.36$ & $4.34 \pm 1.44$ & 0.333 \\
\hline \multicolumn{2}{|c|}{ Vitamin B12 (pg/mL) } & $269.54 \pm 181.17$ & $325.87 \pm 243.97$ & 0.105 \\
\hline \multicolumn{2}{|c|}{ WBC $(\mu \mathrm{l} / \mathrm{mL})$} & $7.45 \pm 1.89$ & $7.58 \pm 1.89$ & 0.676 \\
\hline \multicolumn{2}{|c|}{$\operatorname{MCV}(f L)$} & $80.23 \pm 10.66$ & $80 \pm 6.49$ & 0.857 \\
\hline \multicolumn{2}{|c|}{ Vitamin D (ng/mL) } & $9.09 \pm 3.06$ & $10.49 \pm 3.12$ & 0.009 \\
\hline \multicolumn{2}{|l|}{ NLR } & $2.07 \pm 0.93$ & $2.11 \pm 1.01$ & 0.834 \\
\hline \multicolumn{2}{|l|}{ PLR } & $108.95 \pm 42.08$ & $111.64 \pm 51.43$ & 0.720 \\
\hline \multirow{3}{*}{ BMD } & Osteoporosis & $21(30.4 \%)$ & $26(26.3 \%)$ & \multirow{3}{*}{0.785} \\
\hline & Osteopenia & $18(26.1 \%)$ & $25(25.3 \%)$ & \\
\hline & Normal & $30(43.5 \%)$ & $48(48.5 \%)$ & \\
\hline
\end{tabular}


Table 2. Regression analysis of relationship factors with VAS pain score in osteoporosis and normal BMD patients

\begin{tabular}{|c|c|c|c|c|c|c|c|c|c|}
\hline & \multicolumn{8}{|l|}{ VAS pain score } \\
\hline & & \multicolumn{4}{|l|}{ Osteoporosis } & \multicolumn{4}{|l|}{ Normal BMD } \\
\hline & & \multicolumn{2}{|l|}{ Univariate } & \multicolumn{2}{|l|}{ Multivariate } & \multicolumn{2}{|l|}{ Univariate } & \multicolumn{2}{|l|}{ Multivariate } \\
\hline & & $\begin{array}{l}\text { OR } \\
(95 \% \mathrm{Cl})\end{array}$ & $\mathbf{p}$ & $\begin{array}{l}\text { OR } \\
(95 \% \mathrm{Cl})\end{array}$ & $p$ & $\begin{array}{l}\text { OR } \\
(95 \% \mathrm{Cl})\end{array}$ & $p$ & $\begin{array}{l}\text { OR } \\
(95 \% \mathrm{Cl})\end{array}$ & $p$ \\
\hline \multicolumn{2}{|c|}{ Age (year) } & $\begin{array}{l}1.107 \\
(1.030-1.189)\end{array}$ & 0.005 & $\begin{array}{l}1.094 \\
(1.018-1.175)\end{array}$ & 0.014 & $\begin{array}{l}1.134 \\
(1.031-1.248)\end{array}$ & 0.010 & $\begin{array}{l}1.157 \\
(1.045-1.280)\end{array}$ & 0.005 \\
\hline \multicolumn{2}{|c|}{ CRP (mg/L) } & $\begin{array}{l}0.923 \\
(0.711-1.198)\end{array}$ & 0.549 & - & - & $\begin{array}{l}0.992 \\
(0.919-1.070)\end{array}$ & 0.831 & - & - \\
\hline \multicolumn{2}{|c|}{ Calcium (mg/dL) } & $\begin{array}{l}0.473 \\
(0.143-1.559)\end{array}$ & 0.219 & - & - & $\begin{array}{l}1.714 \\
(0.587-5.004)\end{array}$ & 0.324 & - & - \\
\hline \multicolumn{2}{|c|}{ Phosphorus (mg/dL) } & $\begin{array}{l}2.221 \\
(0.707-6.973)\end{array}$ & 0.172 & - & - & $\begin{array}{l}1.199 \\
(0.377-3.813)\end{array}$ & 0.758 & - & - \\
\hline \multicolumn{2}{|c|}{ Sodium (mmol/L) } & $\begin{array}{l}1.184 \\
(0.950-1.476)\end{array}$ & 0.132 & - & - & $\begin{array}{l}1.067 \\
(0.844-1.349)\end{array}$ & 0.586 & - & - \\
\hline \multicolumn{2}{|c|}{ Potassium (mmol/L) } & $\begin{array}{l}0.904 \\
(0.616-1.326)\end{array}$ & 0.604 & - & - & $\begin{array}{l}2.254 \\
(0.402-12.628)\end{array}$ & 0.355 & - & - \\
\hline \multicolumn{2}{|c|}{ Sedimentation $(\mathrm{mm} / \mathrm{hr})$} & $\begin{array}{l}0.991 \\
(0.964-1.019)\end{array}$ & 0.522 & - & - & $\begin{array}{l}1.034 \\
(0.985-1.086)\end{array}$ & 0.177 & - & - \\
\hline \multicolumn{2}{|c|}{ Vitamin B12 (pg/mL) } & $\begin{array}{l}1.002 \\
(0.999-1.005)\end{array}$ & 0.131 & - & - & $\begin{array}{l}1.000 \\
(0.997-1.004)\end{array}$ & 0.869 & - & - \\
\hline \multicolumn{2}{|c|}{ WBC $(\mu \mathrm{l} / \mathrm{mL})$} & $\begin{array}{l}1.136 \\
(0.868-1.487)\end{array}$ & 0.353 & - & - & $\begin{array}{l}0.914 \\
(0.691-1.211)\end{array}$ & 0.532 & - & - \\
\hline \multicolumn{2}{|c|}{$\operatorname{MCV}(f L)$} & $\begin{array}{l}0.996 \\
(0.952-1.043)\end{array}$ & 0.878 & - & - & $\begin{array}{l}1.018 \\
(0.891-1.163)\end{array}$ & 0.796 & - & - \\
\hline \multicolumn{2}{|c|}{ Vitamin D (ng/mL) } & $\begin{array}{l}1.111 \\
(0.930-1.328)\end{array}$ & 0.247 & - & - & $\begin{array}{l}1.008 \\
(0.815-1.247)\end{array}$ & 0.942 & - & - \\
\hline \multicolumn{2}{|l|}{ NLR } & $\begin{array}{l}1.026 \\
(0.724-1.454)\end{array}$ & 0.885 & - & - & $\begin{array}{l}0.977 \\
(0.541-1.766)\end{array}$ & 0.939 & - & - \\
\hline \multicolumn{2}{|l|}{ PLR } & $\begin{array}{l}1.004 \\
(0.993-1.015)\end{array}$ & 0.489 & - & - & $\begin{array}{l}1.002 \\
(0.994-1.010)\end{array}$ & 0.658 & - & - \\
\hline \multirow{2}{*}{ BMI } & $\mathrm{BMI} \geq 30$ & $\begin{array}{l}0.185 \\
(0.051-0.677)\end{array}$ & 0.011 & $\begin{array}{l}0.225 \\
(0.055-0.928)\end{array}$ & 0.039 & $\begin{array}{l}0.536 \\
(0.159-1.804)\end{array}$ & 0.314 & $\begin{array}{l}0.308 \\
(0.074-1.285)\end{array}$ & 0.106 \\
\hline & BMI $<30$ & $\begin{array}{l}0.971 \\
(0.840-1.009)\end{array}$ & 0.077 & - & - & $\begin{array}{l}1.111 \\
(0.991-1.245)\end{array}$ & 0.070 & - & - \\
\hline
\end{tabular}

\section{Discussion}

In our study, we found that the VAS pain score was higher in the elderly obese group than in a non-obese group. Additionally, in the present study, increased age and $\mathrm{BMI} \geq 30$ were found to be associated with VAS pain score in osteoporosis, and only increased age was found to be associated with VAS pain score in normal BMD patients.

Osteoporosis and obesity can be treated as the most important health problems worldwide. The aging of the world population, changes in dietary habits and increasing sedentary life, increases the rate of these diseases, and acute and chronic diseases such as heart disease, diabetes, and bone fractures. However, the rates of acute and chronic diseases such as diabetes, heart disease, and bone fractures are increasing because of osteoporosis and obesity (17). Nowadays, osteoporosis and obesity prevention and treatment are carried out to reduce treatment costs, minimize and prevent diseases worldwide. In the treatment of osteoporosis, drugs that inhibit bone resorption such as bisphosphonates, calcium, calcitonin, vitamin $\mathrm{D}$, and regulate bone formation such as parathyroid hormone and strontium salts reused (18). Otherwise, lifestyle changes essential as much as the medications as mentioned above 
Table 3. Regression analysis of relationship factors with VAS pain score in patients

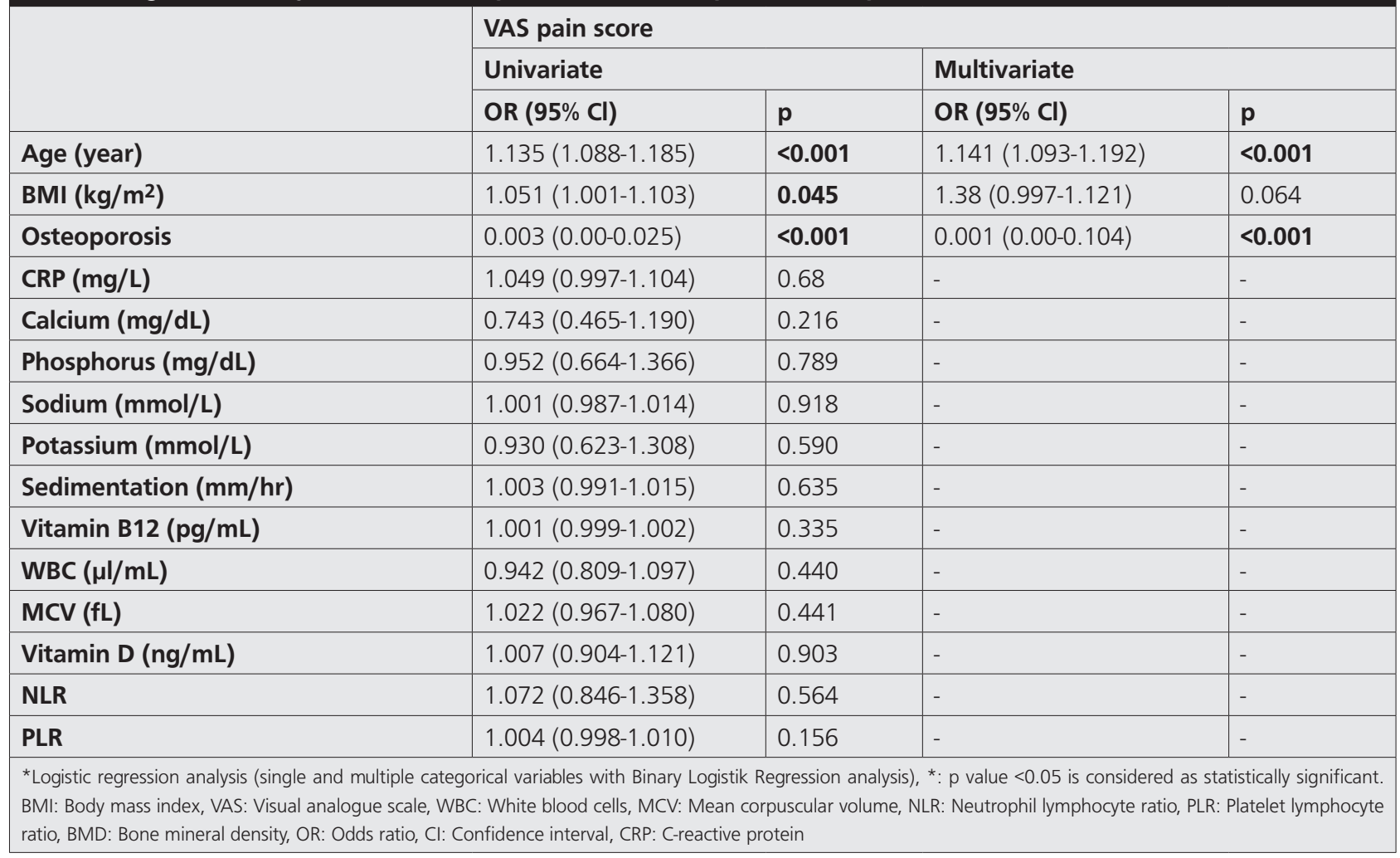

for the prevention of osteoporosis (18). Chen et al. (19) reported that obesity was associated with low BMD and additionally showed a significant relationship between increased BMI and low BMD. llich et al. (20) observed that bone and muscle mass decreased with increasing fat content, and as a result, they stated that immobilization, bone fracture rate, and pain increased. However, some studies suggest that obesity may be protective against osteoporosis and osteopenia in the elderly population (21). Some research shown that pain and obesity were positively correlated in elderly patients, and obesity was a risk factor in the development of pain and decreased the quality of life (22). National Institute for Health and Care Excellence stated that weight loss is an important treatment for pain management. Pain leads to a decrease of mobilization, loss of walking, and balance (23), restricts physical activity and increases the risk of falling in elderly patients $(24,25)$. Increased pain and bone fracture rates are serious morbidity and mortality reasons in patients with osteoporosis (26). In light of the studies as mentioned above, it is seen that osteoporosis and obesity are important factors in pain formation and also treating these diseases reduces pain and improves the quality of life in the elderly population.

\section{Conclusion}

As a result of our study, we found that obesity and age are important risk factors that increase VAS pain score in elderly osteoporosis patients. We think that decreasing obesity, which is a variable risk factor, will benefit reduction pain and sedentary lifestyle and improve BMD in patients with osteoporosis. Limitations of our study were the absence of other biochemical markers in which BMD was evaluated, and lack of assessment of elderly life quality scale.

\section{Ethics}

Ethics Committee Approval: The study protocol was approved by the Necmettin Erbakan University Meram Faculty of Medicine Local Ethics Committee (approval date: 05.04.2019, decision no: 1794).

Informed Consent: All participants provided a written informed consent.

Peer-review: Internally peer-reviewed.

Financial Disclosure: The author declared that this study received no financial support.

\section{References}

1. Schulman RC, Weiss AJ, Mechanick JI. Nutrition.Bone and aging: an integrative physiology approach. Curr Osteoporos Rep 2011;9:184-95.

2. Hernlund E, Svedbom A, Ivergard M, Compston J, Cooper C, Stenmark J, et al. Osteoporosis in the European Union: Medical Management, Epidemiology, and Economic Burden. A report prepared in collaboration with the International Osteoporosis Foundation (IOF) and the European Federation of Pharmaceutical Industry Associations (EFPIA). Arch Osteoporos 2013:8:136.

3. https.//www.sheffields.ac.uk/NOGG/NOGG\%20Guideline $\% 20$ 202017

4. Okifuji A, Hare BD. The association between chronic pain and obesity. J Pain Res 2015;8:399-408. 
5. Hu Y, Tan LJ, Chen XD, Liu Z, Min SS, Zeng Q, et al. Identification of Novel Potentially Pleiotropic Variants Associated With Osteoporosis and Obesity Using the cFDR Method. J Clin Endocrinol Metab 2018;103:125-38

6. Neglia C, Argentiero A, Chitano G, Agnello N, Ciccarese R, Vigilanza $A$, et al. Diabetes and Obesity as Independent Risk Factors for Osteoporosis: Updated Results from the ROIS/EMEROS Registry in a Population of Five Thousand Post-Menopausal Women Living in a Region Characterized by Heavy Environmental Pressure. Int J Environ Res Public Health 2016;13:1067.

7. Fassio A, Idolazzi L, Rossini M, Gatti D, Adami G, Giollo A, et al. The obesity paradox and osteoporosis. Eat Weight Disord 2018;23:293-302

8. Iwamoto J, Takeda T, Sato Y, Uzawa M. Comparison of the effect of treatment with etidronate and alendronate on lumbar bone mineral density in elderly women with osteoporosis. Yonsei Med J 2005:46:750-8.

9. Ohtori S, Akazawa T, Murata $Y$, Kinoshita T, Yamashita M, Nakagawa K, et al. Risedronate decreases bone resorption and improves low back pain in postmenopausal osteoporosis patients without vertebral fractures. J Clin Neurosci 2010;17:209-13.

10. Sahin N, Karahan AY, Atik A, Dogan E, Gezer IA, Ugurlu H. Assessment of the relationship between pain, psychological status, quality of life, and body mass index. Aristotle Univ Med J 2016;42:13-21.

11. Mohd Sallehuddin S, Mohamad Nor NS, Ambak R, Abdul Aziz NS Mohd Zaki NA, Omar MA, et al. Changes in body pain among overweight and obese housewives living in Klang Valley, Malaysia: findings from the MyBFF@home study. BMC Womens Health 2018;18:101.

12. Kanis JA, Cooper C, Rizzoli R, Reginster JY; Scientific Advisory Board of the European Society for Clinical and Economic Aspects of Osteoporosis and Osteoarthritis (ESCEO) and the Committees of Scientific Advisors and National Societies of the International Osteoporosis Foundation (IOF). Executive summary of the European guidance for the diagnosis and management of osteoporosis in postmenopausal women. Calcif Tissue Int 2019;104:235-23.

13. Medical Advisory Secretariat. Utilization of DXA Bone Mineral Densitometry in Ontario: An Evidence-Based Analysis. Ont Health Technol Assess Ser 2006;6:1-180.

14. Hawker GA, Mian S, Kendzerska T, French M. Measures of adult pain. Arthritis Care Res 2011;63:240-52.
15. Macdonald N. World Health Organization Cancer Pain Relief. Geneva: Worl Health Organization. J Palliat Care 1986;1:31.

16. Faul F, Erdfelder E, Lang AG, Buchner A. G*Power 3: a flexible statistical power analysis program for the social, behavioral, and biomedical sciences. Behav Res Methods 2007;39:175-91.

17. Williams EP, Mesidor M, Winters K, Dubbert PM, Wyatt SB. Overweight and Obesity: Prevalence, Consequences, and Causes of a Growing Public Health Problem. Curr Obes Rep 2015;4:36370.

18. Black DM, Rosen CJ. Clinical Practice. Postmenopausal Osteoporosis. N Engl J Med 2016;374:254-62.

19. Chen YY, Fang WH, Wang CC, Kao TW, Chang YW, Wu CJ, et al. Body fat has stronger associations with bone mass density than body mass index in metabolically healthy obesity. PLoS One 2018:13:e0206812.

20. Ilich JZ, Inglis JE, Kelly OJ, McGee DL. Osteosarcopenic obesity is associated with reduced handgrip strength, walking abilities, and balance in postmenopausal women. Osteoporos Int 2015;26:2587-95.

21. Santos VRD, Christofaro DGD, Gomes IC, Júnior IFF, Gobbo LA.The relationship between obesity, sarcopenia, sarcopenic obesity, and bone mineral density in elderly subjects aged 80 years and over. Rev Bras Ortop 2017;53:300-5.

22. Taylor R Jr, Pergolizzi JV, Raffa RB, Nalamachu S, Balestrieri PJ. Pain and obesity in older adult. Curr Pharm Des 2014;20:6037-41.

23. Leveille SG, Bean J, Bandeen-Roche K, Jones R, Hochberg M, Guralnik JM. Musculoskeletal pain and risk for falls in older disabled women living in the community. J Am Geriatr Soc 2002;50:671-8.

24. Stubbs B, Binnekade TT, Soundy A, Schofield P, Huijnen IP, Eggermont $\mathrm{LH}$. Are older adults with chronic musculoskeletal painless active than older adults without chronic pain? A systematic review and meta-analysis. Pain Med 2013;14:1316-31.

25. Stubbs B, Binnekade T, Eggermont L, Patchay S, Sepehry A, Eggermont L. Pain and the risk for falls in community-dwelling older adults: a systematic review and meta-analysis. Arch Phys Med Rehabil 2014;95:175-87.

26. Tanaka S, Yoshida A, Kono S, Oguma T, Hasegawa K, Ito M. Effectiveness of elcatonin for alleviating pain and inhibiting bone resorption in patients with osteoporotic vertebral fractures. J Bone Miner Metab 2017;35:544-53. 